\title{
ON THE INTER-GENRE TRANSITIONS OF LAMENTS AND KALEVALA-METRIC SONGS IN THE BALTO-FINNIC CULTURAL SPACE1
}

\section{MADIS ARUKASK}

The present paper discusses the connection of necromantic songs, spread in the Kalevala-metric tradition of the BaltoFinnic peoples, with burial laments as a possible source genre. The ways and reasons of how and why originally religious themes have taken on an increasingly ballad-like character, are examined. Differences are observed in the folkloric genre systems of various peoples. Also, the connection of such differences with peculiarities of way of life are discussed. Keywords: Kalevala-metric songs, ballads, laments, BaltoFinnic peoples, genres.
Članek govori o povezavi med nekromantičnimi pesmimi, razširjenimi $v$ t. $i$. stopični tradiciji ljudskih pesmi epske pesnitve Kalevala med baltsko-finskim prebivalstvom, s pogrebnimi žalostinkami, slednje pa naj bi bile žanrska podlaga za prve. Raziskane so poti in razlogi, kako in zakaj so izvirno verske teme dobile prevladujoč baladni značaj. Avtor je opazoval različnosti $v$ žanrskem sistemu in pri različnih narodih. Prav tako je bilo raziskano, kakšne so bile povezave med temi razlikami glede na način življenja posamičnih narodov in etnij.

Ključne besede: stopične pesmi epske pesnitve Kalevala, balade, žalostinke, baltsko-finski narodi, žanri.

\section{INTRODUCTION}

The Kalevala-metric (KM) song tradition of Estonians and other Balto-Finnic peoples (Finns, Karelians, Izhorians, Votes, Setus) may be as old as 3000 years. ${ }^{2}$ Thus, it is an archaic genre which up to the $20^{\text {th }}$ century existed side by side with the newer end-rhyming folk song. In a couple of regions in Estonia, the tradition of singing KM songs has survived into the present. Both in Finland and Estonia, scientific collecting of KM songs began in the $19^{\text {th }}$ century, hand in hand with the movement of national awakening which at that time gathered momentum in both those countries, utilizing the folkloric tradition in the important role of a cornerstone to the new modern identity. It was the collecting trips of the Finnish scholars, in particular, that headed further into the East - to Karelia and Ingermanland - in search of KM songs. Estonian researchers, however, took a keener interest in the rich song tradition of the Setus who inhabited areas to the South-East of Estonians. The archive corpus of Estonian and Setu songs comes from the end of the 19th and first half of

1 This research was supported by the European Union through the European Regional Development Fund (Center of Excellence CECT) and by the Estonian Science Foundation (research grant no. 7385).

2 On the KM song tradition in general, see for example articles in Siikala and Vakimo 1994, about Estonian KM tradition for example Ross and Lehiste 2001: 5-35. 
the 20th centuries, thus displaying features characteristic of the songs of that epoch - that is, the partial fading of the tradition and feminization of its subject matters and viewpoints.

Even though the Estonian KM songs include very archaic mythological motifs and rudiments of more ancient epic forms, their main body is, nevertheless, lyrical or lyro-epical. As for the latter, the emphasis is decisively on ballad-like themes and aesthetics. These may have been introduced into the song tradition at a relatively late period -beginning, at the earliest, perhaps with the $17^{\text {th }}$ century or even later, when the cultural (including poetic) influences of renaissance and modernity began to penetrate the popular culture of Europe's more peripheral areas. The surviving KM songs of the period represent a kind of mixed genre, wherein a stratum of new themes and attitudes has formed on top the ancient Kalevalacode, the one-time poetic sacral language of the Balto-Finnic peoples (cf. Kuusi 1994: 41 ff.). At the same time, the change is not unidirectional towards innovation - the ancient poetic metre and its inherent logic (as well as the compositional peculiarities of oral culture, of course) "break up" the more modern themes, and the story-patterns presented by the songs are rather rudimental and therefore hard to follow, perhaps even incomprehensible, especially to the modern man at home in a written literary tradition. It would seem that in addition to international loan stories - like family dramas and stories of manslaughter -, there has, in numerous cases, occurred a symbiosis of some old mythological and shamanistic theme with a newer, person- and conflict-centred stratum. It is a section of that latter kind of texts - namely KM necromantic poetry - that the present article discusses. Those are songs describing a person's relationship with his or her dead relatives which also include corresponding dialogues, characteristic of the ballad genre. The question raised here is about the genre-specific genesis of those songs. At the same time, attention will be paid to the aspect of customary observances, and on the possible function of the songs in a traditional society.

In addition to the songs, my interests as a researcher have in recent years bent towards a more ancient genre - the burial laments. In Estonian and Finnish popular cultures, subjected to Lutheran influences, lament as a genre is unknown. Obviously the practice of conversing with and commemorating the dead through ritual weeping has, over the centuries, eroded from the tradition. In North-East Europe, however, lamenting is well preserved among those Balto-Finnic peoples who have lived within a Greek Catholic cultural context (the Karelians, Vepsians, Izhorians, Votes), naturally also among (northern) Russians, as well as among several more easterly Finno-Ugric peoples in the northern parts of Russia. On a few occasions, during my field-work in Vepsian villages, I have had the opportunity to document lamenting in ritual situations - an experience that has given rise to closer interest in the social function of the phenomenon, as well as in whether, how and what may compensate for its lack in cultures that have lost the practice of lamenting (like the Estonian or Finnish cultures).

Lamenting has survived into relatively recent times (or even into the present) not only in North Russia, but also among South European nations - the Hungarians, Greeks, 
and others. From a modern point of view, it might thus be classified as a East European phenomenon, as it were; a phenomenon that is distributed along an imaginary axis from North Russia down into the Balkans (cf. Honko 1974: 13-14). Being better acquainted with the specific features of northern Europe, I shall in this paper focus mainly on that region.

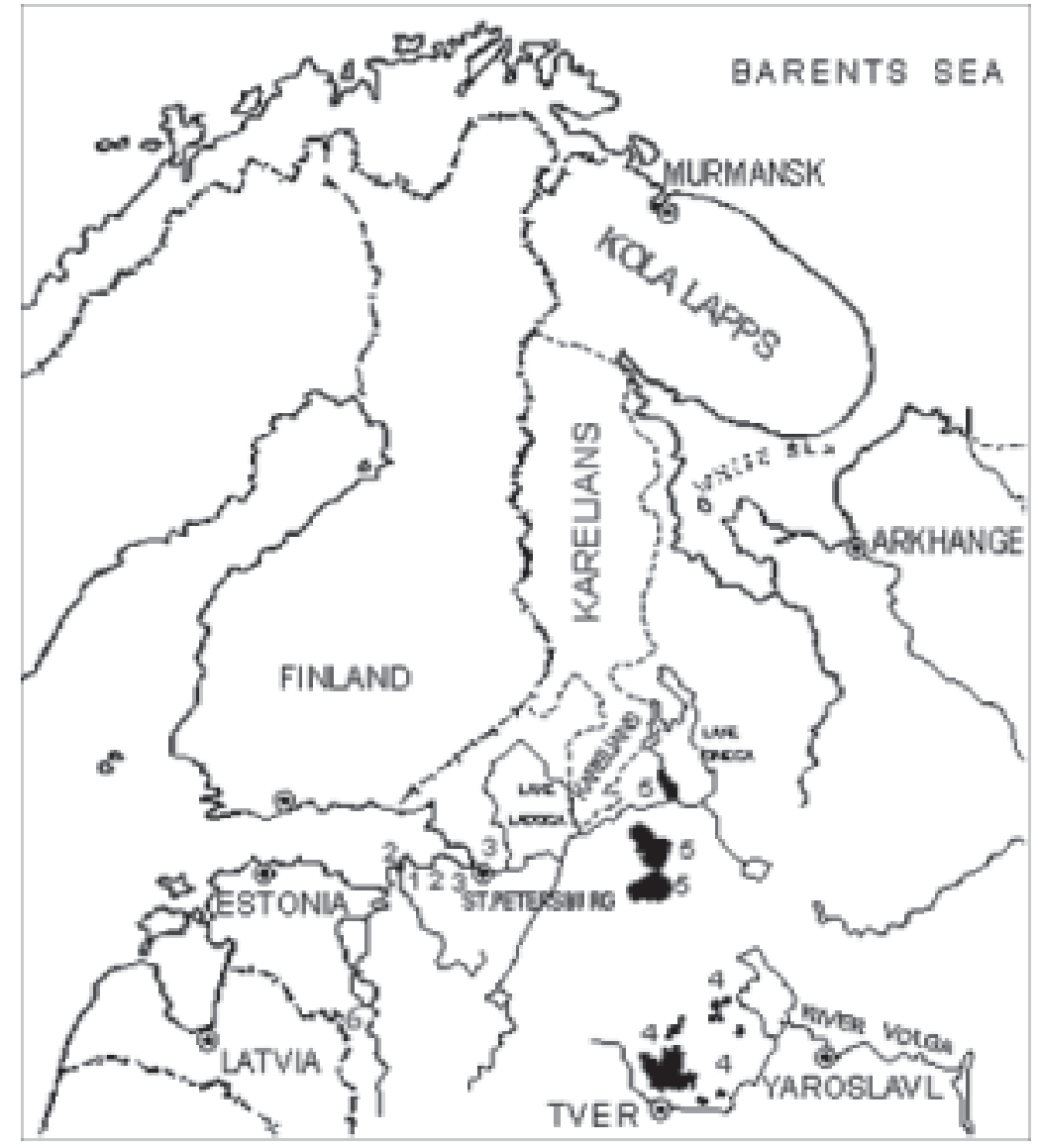

Baltic-Finnic Peoples of Northwestern Russia: 1 Votes, 2 Izhorians, 3 Ingrians, 4 Karelians, (Tver), 5 Vepsians, 6 Setus.

\section{NECROMANTIC POETRY IN BALTO-FINNIC POPULAR CULTURE}

It is remarkable that the inter-genre relations between laments and ballads/songs are different among various Balto-Finnic peoples. In Karelia and North Russia, lamenting as a poetic code is relatively autonomous of the rest of the song tradition (cf. Honko 1974: 1920; Čistov 1982: 104, 110-111; Nenola-Kallio 1982: 79-81). The poetics and language of the laments is very rich, indeed epically monumental there. The poetic vocabulary and the 
manner of its operation form an independent system, with few offshoots into other poetic genres. Similarly, lamenting is metrically quite liable to change there, and may seem very spontaneous - that is, not at all song-like - to one ignorant of the practice. Lament as a performance, as I can assert from my own direct experience, is also completely different from singing there. Vocally, it constitutes a rather more speech-like technique, where, judging by the European musical standard, the text is intoned "incorrectly" or non-contemporarily.

Popular religion props this way of performance up by the traditional belief that it is precisely that mode of vocal and poetic addressing that can reach the deceased, so that he will be able to hear and comprehend it (for example Honko 1974: 38, 57). Thus, the association and the causal explanation of the peculiar monumentality of the genre are very functional. Moving on to the more southerly Balto-Finnic peoples, however, we find a different situation. Lamenting tradition is present here among the ethnic groups of the historical Ingermanland - the Votes, the Izhorians and, curiously, also the Lutheran Finns (Ingrians) inhabiting that area. Finns settled in Ingermanland in the $17^{\text {th }}$ century when, as a result of the Swedish-Russian wars, the territory temporarily formed part of the Swedish kingdom and underwent an attempt at repopulation with Lutherans (Kolga et al. 1991). It may, however, be presumed that in many cases, former Izhorians were induced to adopt a Finnish identity, which in turn would explain the practising of lamenting among the local Finns.

Compared to the lamenting tradition of Karelians, Vepsians and North Russians, that of the above-mentioned peoples of Ingermanland is much closer to the KM song tradition. In the tradition of the Setus, inhabiting South-East Estonia and areas on both sides of the border with Russia, lamenting and singing share an even greater amount of common features; here, it would often be justified to speak about laments transformed into singing, both in the poetic and the musical sense. The lamenting tradition of the Setus and also of the peoples of Ingermanland is relatively close to the stratum of necromantic poetry in the KM songs. Remarkably, such songs can be found not only in the tradition of the Votes and Setus, but also among Estonians, raising the question of what might be the origin and function of those songs here.

Characteristically, such necromantic songs describe a communication situation whereby the feminine first-person protagonist of the lyrical or lyrical-epical KM song enters into communication with a dead and buried relative (on this issue, see also Valk 2000; Lintrop 2001; Arukask 2004; also see examples of Estonian texts in the Appendix). In the majority of cases, the deceased is mother (and/or father) like, for instance, in the Estonian song type "On Mother's Grave"; in Ingermanland it may also be brother - in any case, it is a close blood relation, not anyone else. ${ }^{3}$ The aim of the communication is to plead for help; frequently the plea is occasioned by preparations for getting married - the mother is invited in the song to prepare the dowry. Among the necromantic songs of the

3 During my fieldwork, I have even heard some Vepsian lamenters claim that lamenting for a dead husband - a person not related by blood - is altogether improper and unjustified. 
Setus, mother's conversations with her dead daughter can be found, too. In that case, too, the wedding allegory is prominent - the daughter is said to have "married a dead man", that is Death himself, and the mother may expect her (according to the wedding customs) to come to see her father's home for one last time. However, here it must be kept in mind that the allegoric and, as concerns the customs observed on each occasion, even concrete identification of death and marriage (as liminal rites) has been wide-spread among many peoples in various parts of the world (cf. Honko 1974: 51-52; Bernshtam 1979: 140-145; Čistyakov 1982: 119-120; Baiburin and Levinton 1990).

Besides pleading for help, the second feature characteristic of the communication is emotionality - the person visiting the grave (who is often also an orphan) longs for the support of the deceased which she deeply misses. A common motif in KM songs, in this connection, is the invitation to "stretch a hand out of the sand". Thus, a mental effort is made to overcome the separation even physically; in quite a few texts, the lamenter catches a glimpse of a familiar piece of clothing in the opening grave. Yet those attempts at contact described in the songs remain futile. At best, the unfolding dialogue reveals the impossibility of resurrecting the loved one and receiving help from her; even though the mourner is consoled, the consolation remains primarily psychological. Even if the helping activities of the deceased parents are actually described (as in one of the examples presented here), it is still rather allegorical, offering moral support to the protagonist of the song (and her sympathizers).

Such communication situations described in the songs may be initiated by the mourner(s) pleading for help who visit the grave. In several songs, however, the contact is described as happening incidentally, as a result of a girls' throwing game. As the projectiles are thrown, one of them flies into a graveyard (or church road, or into the heaven, etc) and lands with a clop on the coffin's lid, sometimes even breaking it. This can be seen as a onetime ritual preparation for establishing a relationship with the otherworld, perhaps even a special (magical, shamanistic) manipulation in order to cross the boundary between this world and the other.

Characteristically of the lyrical-epic discourse, such primeval elements remain mere vague substratal implications in the texts. The Estonian, Setu and Ingrian songs all alike are dominated by a sense of fatalistic inability to change reality and of being subjected to a higher law. Juri Lotman (1984) has described the religious model of culture and its characteristic type of relationship between this world and the other as unequal and underpinned mainly by mere hope. A magic relationship, on the contrary, is one between equal partners, characterised by the logic of exchange, reciprocal activity and a "juridical" nature sometimes taken even to the point of contractuality. It is in the border areas between those two types of relationships that the necromantic song texts move. The texts "remember" one-time beliefs according to which contacting the deceased and even his/ her resurrecting were part of a magical reality, while the singers of the final decades of the $19^{\text {th }}$ century have clearly been stuck with a more recent religious persuasion which did not 
allow for a deceased's resurrection before the Last Judgement. Therefore, in those songs, even a dialogue with a deceased mother or brother constitutes not magical negotiations, but rather a kind of psychologized poetry. ${ }^{4}$

The latter, however, is particularly closely connected to ballad as a genre. A relatively unmystical, practical act of communication has turned into a kind of eerie story that puts personal suffering in the foreground, even though it may not yet happen very convincingly in the archaic KM song. All the earlier mythological motifs have also turned into curious details. The projectile's clop on the coffin lid which, as a mythologem, ought to be interpreted as a sign of important changes in the course of events, a kind of discoursive marker, has in the ballad been reduced into a mere argument preceding an even more shocking event - the opening of the grave and/or coffin. Undoubtedly, similar stylistic features characteristic of ballads have emerged and been polished to a far greater subtlety in the more modern European tradition of end-rhyming ballads. The Balto-Finnic KM song remains, in this respect, primarily an interesting transition genre, bridging the gap between the earlier lamenting code and the topicality of the modern ballad. So what have been the factors, besides the above-mentioned pressure of clerical authorities (in the Lutheran cultural space) and the imported fashions of modernity, that have brought about the disappearance of laments (primarily burial laments) in the Estonian tradition, and their transformations into more song-like recitals among the Setus and the Ingrians?

\section{SOME REASONS FOR INTER-GENRE TRANSITIONS}

It should be possible to explain the transformation of lamenting as a poetic genre and practice into more song-like recitals with some broader social factors. That is what I attempt to do in the following analysis.

Perhaps the most universal and important problem within the broad subject of human beings and death, in all archaic cultures, is the posthumous relationship between the living and the dead, more precisely the fear of the dead, its suppression and control. It can be said that a major part of all the death-related customs of various peoples is dedicated to this topic. In addition to behavioural observances (like the commandments and taboos related to the burial situation, customs related to remembering the dead, etc), it also concerns the relevant poetic texts. As an act of speech and a communication strategy, lament makes a substantial contribution into such (magical) diplomatic relations with the deceased. In the summer of 2005, during fieldwork in South Karelia, I had the opportunity to record

4 Particularly in folk cultures with Lutheran superstratum (as, for example, the Estonian one), have not, for religious reasons, favoured the Catholic "magical" subordination of the dead to clerical jurisdiction (cf., e.g. Martin Luther's "Disputatio pro Declaratione Virtutis Indulgentiarum", theses 8-29), the impact of which is visible also in the gradual suppression and disappearance of lamenting as a practice in the Finnish and Estonian cultures, for instance. 
about half an hour of lamenting (in Russian), when an old woman lamented on the grave of her husband who had passed away about a year earlier. The performance began with a typical ritual waking up of the deceased; next, he was informed, through the lament, of the problems of daily life encountered in this world; then he was asked to pass on greetings to the relatives sojourning in otherworld, and finally urgently requested not to interfere with the lamenter's daily life by visiting his former home at night - she was namely convinced that her husband had been paying nightly visits to their house.

The above-mentioned motif of clattering, present in the KM songs as a discoursive marker that signified the beginning of setting up relations with the deceased is also represented in the texts of laments. North Russian laments begin with an invitation to the elements to come and wake up the deceased:

Уж ть дай-ко богородии, ,

Только ветры неустойные.

Ужк вы повейте, ветерочики,

Разнесите-ко песочики!

Тьь раскройся, гробова доска,

Покачнись-ко тело мертвое,

Тьь, личушко же блеклое!

Уж ты дай-ко богородица,

В ясны очушки-то зреньище,

Вустаже - говореньице,

В бельь ручушки - маханьице.

В резвыноженьки - хоженьице!

(Vinogradov and Lozanova 1941: 109)
Oh, Mother of God, give

Restless winds only.

Oh, blow winds,

Scatter the sand!

You, stave of coffin, open up,

Incline yourself, dead body,

You, white face!

Oh, Mother of God, give

Sight to the bright eyes,

Speech to the mouth,

Waving to the white hands,

Walk to the fast legs!

The primordial element (stormy wind, roaring and clattering) has been not only described, but also imitated in practice. In the above-mentioned lament performance, the lamenter made sweeping, wind-raising movements above the grave with a scarf she had brought along. Also, upon arriving on the grave, she uttered the words: 3дравствуй дедушка, Христос воскрес! Все покойнички приили (Welcome, daddy, Jesus has risen, all the deceased have come), thereby carrying out a cosmogonic act of awakening, as it were, the specific function of which was to begin communication with the deceased according to the relevant customs (Vinogradov and Lozanova 1941: 109; Baiburin and Levinton 1990: 82-83; also Honko 1974: 29-30).

Thus, the lamenting session as such exemplifies the legal possibilities for communicating with the dead, begun by inviting the deceased to rise and concluded by sending him back, as it were. Although a large part of the textual body of the given lament consisted in the lamenter's personal and deeply tragic complaining of her current situation and forlornness, this is not quite related to the modern person-centred problems characteristic of the ballad. The point is that in the laments, descriptions of personal misery and forlornness verge on a 
kind of accusing of the deceased. Thus, a very practical magical struggle between this world and the other takes place in the laments, in which the lamenter is a kind of gate-keeper and a medium. In Setu laments (see example in the Appendix), there occur attempts to bring personified death to justice, and the attitude towards a newly deceased person may be quite aggressive. An accusing attitude towards the deceased is very characteristic of Russian laments, especially immediately after death (Vinogradov and Lozanova 1941: 106-107).

Hence it is understandable why lament in its earlier forms and functions (as it can be observed in Karelia and North Russia) is rather a technique than poetic creation. In 2007 and 2008, I recorded another Vepsian lamenter whose behaviour on the graves of her loved ones indeed resembled technical work - she was able to enter very quickly into the state of possession required for lamenting, and also to come out of this state very fast. Lauri Honko (1978) has viewed the lamenter as a shamanistic expert of otherworld. The lamenter is thus a professional who actually can't afford any artistic or emotional "weaknesses" but must, in the ritual situation, fulfill the social multiple role allotted to her.

The function of singing, however - and especially ballad singing - is to tell a story for entertainment, in which the supernatural, the critical and the terrible have been artistically modelled. Therefore, the "I" of the laments is not really identifiable with the lyrical "I" of the songs. Genre transitions may take place on the textual level, but the emphases are different.

As concerns gender, lamenters in the European cultural space are mainly women, although there are a few examples of men lamenting. In Estonia, Setu and Ingermanland it is indeed women who have, during the last few centuries, also been the main singers of the KM songs. This, in turn, explains the disappearance of the epic KM song tradition in those regions. In Karelia, however (where, as we remember, lament is much more autonomous of the songs), the masculine epic KM song tradition, which Elias Lönnrot used to lay the foundations of the Finnish national epic Kalevala, has been known up to recent times. At the same time, the northern Russians are the last carriers of East Slavic culture who have retained the epic tradition of bylinas. Once again we can note the areal unity of Karelia and North Russia (in spite of the language difference), as opposed to the more westerly and southerly regions and peoples.

Ballads, including the family stories built on shock and conflict, are not unknown in the Karelian-North Russian area, either (cf. Kiuru 1994; also papers in Oinas 1969); but in the general genre system, it is the epic tradition, as well as the above-mentioned epic lament tradition that has remained vigorous up to the present time, which hold a prominent place. The preservation of the epic tradition has been supported primarily by the greater autonomy of the male culture in the North - less employment in agriculture and a greater involvement in hunting and forestry, which have offered men a chance to preserve their own repertoire and register. Such a specificity has probably rather isolated the symbiosis between lament, epics and the ballad, whereas more to the south, we could observe an opposite tendency.

From a social aspect, we might also keep an eye on the cultural specificity connected with collectivity and individuality in the traditions we are scrutinising. One feature of the 
ballad as a modern genre is the emergence of the individual modern "self", capable of opposing himself to the earlier epic collectivity which always set the interests of the clan foremost, and in which the individual, in the modern sense, has been practically non-existent. The masculine epics has rather admired the hero as a champion, without seeing any need for or sense in comparing or even identifying him with the simple suffering human being. In the laments the specificity of the lamenter as a spokesperson of the society and, only after that, as a personal "self", has been particularly well preserved - whereas among the more southerly peoples, where the lament has blended more thoroughly with the KM song, that characteristic is on the wane.

Agricultural patriarchal societies have, as such, been very collective. In them, ballads and ballad singing (as well as the telling of folk tales) have offered a kind of psychological compensation to those who have been socially more marginalized. The desire for individual love and recognition expressed in the ballads may, at some point in time, have constituted one of the very few legal opportunities of self-expression for teenage girls - the main singers of KM songs in Estonia, Setu or Ingermanland -, who lived under the dictate of older members of the extended family. This provided a gateway for the modern, person-centered identity which nowadays may seem so natural and self-evident to us.

Probably, however, the Karelian-North Russian culture had preserved, in addition to the masculine epic forest culture, a more primordial individualism based on personal autonomy, enabled by sparse population, influences of an animistic nature religion, weaker ties with agriculture and husbandry, and removal from administrative centres of power. This kind of a social situation could hardly have avoided exercising an influence on the poetic genres and on functionality in a more general system, explaining, in our case, the more monumental independence of genres in the northerly areas.

Together with social modernization, aesthetic perception and the corresponding preferences have changed, too. In case of the ballad tradition, this means that the onetime pre-Christian mythological reality has gradually lost its persuasiveness, getting rather demonized and shifting into the sphere of entertainment. In the lyrical-epic KM ballads of Estonia, Setu and Ingermanland, it is possible to follow from song to song how the onetime divine characters (like the Estonian Kalevipoeg or the Setu päiväpoigal Sun's son) have been reduced to criminal antagonists. The relatively neutral underworld of the mythological world view has, in the KM ballads, become the realm of demons antagonizing the failed upper-world hero, animistic nature spirits have become murderers, and so on.

Thus we can see how one of the "central arenas" of lament subjects - the otherworld and the deceased sojourning there - begins, in ballads, to forego its ambivalent neutrality and to take on an increasingly negative role in the balladic, conflict-centred way of depiction. The primeval relation of partnership turns into an opposition between this world and the other, the cultural and the extra-cultural, the human and the demonic, which indeed constitutes one of the most characteristic features of the balladic world reflection as compared to the earlier poetic world of the KM songs. It is only in a later, more romantic stage of evolution 
that the pre-Christian and the primeval may restate its value in a new quality - but at least in the KM ballads, this (as yet) is not to be noticed in practice.

In this way, it becomes understandable how laments have been transformed into necromantic ballads - a change contributed to by changes in world view and way of life, gender and social peculiarities in different cultures, but obviously also an intervention of high religion, as far as the suppression of old burial customs was concerned - the latter being the case mainly in the Lutheran cultural space. At the same time, the KM ballads, unlike the newer end-rhyming song tradition, have not completely detached themselves from the customary aspect - necromantic songs have circled (in Estonia, for example) as a substitute for the laments - and it is also known that such songs may have been sung by the bride, visiting the cemetery during the wedding rituals, if any of her close relatives (e.g. one of her parents) was dead (cf. Salve 2000: 67; also Valk 2000: 265). The invitation - through lament - to establish temporarily a legitimate contact with the world of the deceased has been substituted by a poetic invitation to help a maiden about to get married - as revealed by the song texts, themselves.

\section{CONCLUSION}

Several questions, of course, remain unanswered. What becomes of the representation of an immediate grieving relationship when the lament disappears, as it has happened in Estonian and Finnish traditions? One possible answer would be that such self-expression has been channelled into the necromantic songs we have examined, which have also been associated with ritual situations (if not in the burial customs, then at least in the wedding rites). At the same time we might counter with another question: did the older epic culture involve anything like personal grief, at all? Perhaps this has, indeed, emerged only together with a more modern cultural situation, finding its expression in the song-like lament (like the Setu ones), and even more strongly in the KM necromantic (proto-) ballads?

Another issue that remained undiscussed in the present article is the musical aspect of the songs and laments, the role of which in the described processes of change should also not be underestimated. The possibility cannot be excluded that even more modern music may have played a far from insignificant role in the transformation of moods, as well as of the contents of older songs (and perhaps, of the laments), especially in the case of the Ingrian and Setu laments becoming more song-like. Undoubtedly, however, the more modern fashions have exercised a broader influence on the regression of the lament tradition, or on its turning more lyrical and more person-centred, as characteristic of modernity. It is precisely among the Balto-Finnic peoples located closer to the cultural centre of Europe that we can note a greater dynamic of change.

In this respect, the lyrical Balto-Finnic cultural space of the southern and western areas was contrasted by the more northern and eastern areas with their greater use of the epic 
both in their songs and laments. Yet even when observing performers of the contemporary Karelian-North Russian lament tradition, we must keep in mind that they are, regardless of all, people who have inhabited the modern world for a long time, people whose modernized emotional world must inevitably have its impact even on the lament texts created within traditional frameworks. Nevertheless, if the KM form had a conserving and, after its own fashion, recreative impact on the balladic themes penetrating into it, the same can also be said of the Karelian-North-Russian epic lament form which rectifies the emotions of the reciter during the performance, bringing her under greater collective control.

We can also treat the lament as a possible source of themes for the modern ballad. The mythological conceptions which, in reworked form, have added much genre-specific mysticism and thrill to the ballads, may have got handed on not only through the earlier epic tradition, but also through laments - that is valid especially for such regions where lamenting in its original function was able, for a certain period, better to resist the modern changes. Here, the differences between the poetic genre systems of various North European Balto-Finnic peoples offer a good opportunity for modelling and observing that transition.

Finally it should also be underscored that even the KM song tradition surviving into the present cannot be regarded as a mere transition form from the old to the new (as it may have appeared from the present article). It constitutes a poetic code, evolved and crystallized over the centuries, the life span of which in the Balto-Finnic cultural space surpasses many times the age and experience of the end-rhyming - including the balladic - poetry.

\section{APPENDIX}

\section{Estonian necromantic Kalevala-metric Songs}

\section{EMA HAUAL}

Käisin eile Hiielassa, tunaeile Toonelassa, eile eide haua pealla, hauduja südame pealla:

"Tôuse üles, eidekene, tôuse üles, anna armu!"

Eite varsti vastajeli, eite hauasta kôneli: "Ei vôi tôusta, tütar noori, ei saa tóusta, ei ärata! Tooni poeg on pólvillani, Tooni tütar süllessani. Silmil on sinine metsa,

\section{ON MOTHER'S GRAVE}

Yesterday I went to Hiiela (the holy grove), The day before, to Toonela (realm of Tooni/Death), Yesterday on mother's grave, Over the heart of the one that hatched me: "Rise up, mother, dearest, "Rise and be gracious!" Mother soon answered, Spoke from the grave: "I can't rise up, young my daughter, I can't rise, I can't awake! Tooni's son sits on my knees, Tooni's daughter on my lap. Forest blue grows on my eyes, 
jalgul on jalakametsa.

Mine koju, tüttereni,

palu vóerasta isada,

palu vóerasta emada,

hau vóerast haudujatta,

kes sinul istub isaksa,

kes sul astub haudujaksa,

kes sinu piu pidaneb,

kes sinu jäu jäganeb,

kes so lukuvööd lugeneb,

kes sinu sukad sääriteleb,

kes sinu kindad kirjasteleb,

kes sinu vakka valmisteleb,

andevakka asuteleb!"

(Viru-Jaagupi parish, 1889)

(Tedre 1970: 611)

\section{AVANEVAD HAUAD}

Läksin kurni kukutama, höbeöuna veeretama.

Kurn kukkus kirikuaeda,

hóbeouna aia peale.

Lahti läksid haua uksed,

haua uksed, kalmu kaaned.

Seal nägin oma isada

kopikida korjavada,

rublasida lugevada.

Mina isalta küsima:

"Kellel korjad kopikida,

kellel loed rublasida?"

"Sulle ikka, tütar noori!

Sa jäid vara vaesekslapseks, ilma isata elama."

Seal nägin oma emada

kuldakangasta kuduvat,

hōbelónga lōksutavat.

Mina emalta küsima:

"Kellel kuiud kuldakangast,

kellel lóksud hóbelóngu?"

"Sulle ikka, tütar noori!
Elms grow on my feet.

Go home, my daughter,

Ask a foster father,

Ask a foster mother,

Beg a stranger hatcher,

Who would settle to be your father,

Who would step in to be your mother,

Who would make for you the feast,

Who would give to you your share,

Who would count for you your lock-belts,

Who would knit for you your long stockings,

Who would pattern for you your mittens,

Who would prepare your bride's chest,

Set up your dowry casket!"

\section{OPENING GRAVES}

I went off to play hurling,

Went to roll the silver apple.

Into the church-yard dropped my cudgel,

Onto the fence the silver apple.

Open came the doors of the grave,

Doors of the grave, lids of the barrow.

There I saw my father

Hoarding kopecks,

Counting roubles.

I went to ask my father:

"For whom do you hoard the kopecks,

For whom do you count the roubles?"

"It's for you, my daughter young!

Early in life were you orphaned,

Forced to live, fatherless."

There I saw my mother

Weaving a golden cloth,

Clicking away with a silver thread.

I went to ask my mother:

"For whom are you weaving this golden cloth?

For whom are you clicking the silver threads?"

"It's for you, my daughter young! 
Sa jäid vara vaesekslapseks, ilma emata elama."

(Vändra parish, 1868-1869)

(Tedre 1970: 616)
Early in life were you orphaned, Forced to live, motherless."

\section{Setu burial Lament}

/A daughter is wailing for her mother. The daughter is a maiden, still living at home/

Oh sa koolu, kuri miil, oh sa katso, kalgi sö̈,

kuis sa vôtit iist mi ime, var'olt mi vanómba? Jätit meid varra vaesis, inne-aigu armótus, jätit meid külä külele, jätit meid valla var'oló! Keä nakas armu andmahe, kulla sónnu kostmahe? Oh sa koolu, kuri meeli, oh sa katso, kalgi sö̈!! Olós tuu koolu kätte saassiq, olos tuu katso kaiaq saassiq, sis ma koolu ikótasiq, katso meele pahandasiq, kui taa koolu muida ikót', katso pall'o pahha tegi! Sedä ei jóvvaq ohto unóhtada, sedä ei jôvvaq kahjo kannahtada! Imekene helläkene, maamakönõ, mar'akônô! Ime kalmu katôtas, maama maaló matôtas, latsóq jääväq ilma elämähe, jääväq valda vaesós, jääväq külä külele. Pall'o vaiva vaesil, pall'o ikku ilm-imetä: ega kostki tukó tulö[-i], tukó ei tulóq, armu ei astuq, meelüq ei neide meelekene,
O you, death, you evil mind,

O you, plague, heart of stone,

How could you take away our mother,

Pluck away the sheltering parent?

Early in life you left us orphans,

Untimely, without grace,

Left us by the side of the village,

Left us for the parish to shelter!

Who would now take care of us,

Who would tell us words of gold?

O you, death, you evil mind,

O you, plague, heart of stone!

Were I but to catch that death,

Were I to set my eyes on that plague,

Then the death I would make to wail,

Then the plague I would upset,

Like the death made others wail,

Like the plague upset so many!

I have no strength to forget that misery,

I have no strength to bear that loss!

Mother gentle,

Mummy, darling!

Now the mother is covered in grave,

Now the mummy is buried in earth,

Children left to live in this world,

Left as orphans into the parish,

Left by the side of the village.

Great is the misery of the orphans,

Many the tears of the motherless:

Nowhere can they find support,

Find support or feel love,

(No longer) is their mind softened, 
sütüq ei neide sü̈̈mekene!

Käüväq ime kääpäle,

lääväq maama matussóló, sääl naaq sónnoga kónôlósi:

"Maamakónó, mar'akónó, annaq käsi kä̈̈päst, annaq sórmi sómórast, sis meelüs meelekene, sütüs mi sü̈̈mekene! Kui ei annaq kätt kääpäst, anna-i sórmó sómórast, sis ütleq üts sónakónó, maamakönó, mar'akõnō!" "Sorrô liiva suu pääl, kääbäs suuri kässi pääl, liiva lasō-i suud liigutölla, maa ei lasóq suud maigutölla, liiva ei keelt liigutólla!" Maamakónó, mar'akónó, kelle ütle uma oho, kelle kaiba uma kah'o? Kui ollit eloh, imekene, alaló, armukónó, sis sullo_ks ütli uma oho, sis sullo_ks kaipsi uma kah'o. Kui sa koolit, imekene, kattôt, lastô kasutaja, oló-i kellegi kônólda, vôi-i ütelegi üteldä!

(Puugnitsa village, 1874)

(Hurt 1907: 273)
(No longer) are their hearts healed.

They keep going to mother's grave,

Visiting mummy's resting place,

There they tell her, utter the words:

"Mummy, dearest,

Stretch out your hand from the barrow,

Offer your fingers from the sand,

Then our minds would be softened,

Then our hearts would be healed!

If you can't give a hand from the barrow,

If you can't stretch a finger from the sand,

Utter then (at least) a word,

Mummy, dearest!"

"Sheer sand is on my mouth,

Great barrow on my hands,

The sand won't let me use my mouth,

The earth won't let me ope my mouth,

The sand won't let me move my tongue!"

Mother, dearest,

To whom shall I tell of my misery,

To whom shall I complain of my loss?

While you lived (still), mother, dear,

While you were (still) with me, my dear,

Then to you I would tell of my misery,

Even to you would complain of my loss.

After you died, my mother dear,

After you went, your children's support,

No-one remains for me to talk to,

No-one to whom I could complain!

\section{Vepsian burial Lament (beginning)}

/Memorial supper/

Kalliž sina kand'aihudem,

kus sina ladid i kogotas?

Kuna ei lekoi libedad linduižed,

sinna ladid kogotas,
Dear one who bore me

where are you bound for?

Where the lively birds do not fly that is where you are bound for 
kesken kazmatomid (libumatmid) sirotinoid.

Ei raffaline minun sötai taoti se om,

kibedaštši se iškeb,

vilustti se virkaudab,

möha ehtkoižel se panetab,

aigois homesel se noustatab.

Sina kut oližid kalliž kand'aihudem, ed ratsiž meida noustatada.

\section{Mina kuź varastin pitkad nedalid,} nell'küme päiväštšs.

Mina sinadiž tulen noustatamha.

Avaiteske dub grobovi loudaine,

katsaudaske minun goregorkian tütren päle,

i mindain katsu entšikš edelitšikšs,

i meile sanu goregorkioile tütrile

sigalaine elo se!

Kuź me pitkad nedalid varastimoi,

abaroikš armoikš ni,

kakspoližikš abaroikš ni.

(...)

(Honko, Timonen and Branch 1993: 608) half-grown, half-risen orphans.

Father is unkind:

he beats me sorely

he speaks to me coldly

he puts me to bed late

he gets me up early.

If you, dear one who bore me, were here

you would not have the heart to get us up.

I have waited six long weeks

forty days:

I come to get you up.

Please open, oak coffin

please look at me once, a poor daughter

look at me as you used to

and tell us poor daughters

about life there!

Six long weeks we have waited

for our own darlings

for our own parents.

(...)

\section{REFERENCES AND SOURCES}

Arukask, Madis

2004 Time, Sense and Meaning in Three Votic Songs (with Reference to Estonian and Setu Additions). Folklore [Tartu] 28: 129-150 (http://www.folklore.ee/Folklore/vol28/songs.pdf).

Baiburin, A. K. and G. A. Levinton

1990 А. К. Байбурин, Г. А. Иевинтон, Похороны и свадьба. In: Исследования в области балтославянской духовной культурьь. Погребальный обряд. Москва: Наука, 64-99.

Bernshtam, T. A.

1979 Т.А.Бернштам, О «Авойной природе» причета. In: Симпозиум-79 по прибалтийско-финской филологий. Тезисы докладов. Петрозаводск, 138-145.

Čistov, K. B.

1982 Чистов К. В., Причитания у славянских и финно-угорских народов (некоторые итоги и проблемы). In: Обряды и обрядовый фольклор. Москва: Наука, 101-114.

Čistyakov, V. A.

1982 В. А. Чистяков, Представления о дороге в загробный мир в русских похоронных причитания XIX-XX вв. In: Обряды и обрядовый фольклор. Москва: Наука, 114-127. 
Honko, Lauri

1974 Balto-Finnic Lament Poetry. Studia Fennica [Helsinki] 17: 9-61.

1978 The Ingrian Lamenter as Psychopomp. Temenos 14: 82-96.

Honko, Lauri, Senni Timonen and Michael Branch

1993 The Great Bear. A Thematic Anthlogy of Oral Poetry in the Finno-Ugrian Languages. Helsinki: Finnish Literary Society.

Hurt, Jakob

1907 Setukeste laulud. Pihkva-eestlaste vanad rahvalaulud ühes Räpinä ja Vastseliina lauludega III. Helsingi: Suomalaisen Kirjallisuuden Seura (http://www.folklore.ee/rl/pubte/ee/setu/laul/ laul3/g/6.html).

Kiuru, Eino

1994 The Wife-Killer Theme in Karelian and Russian Songs. In: Sikkala and Vakimo (eds.) 1994, 220-235.

Kolga, Margus, Igor Tõnurist, Lembit Vaba, Jüri Viikberg

1991 The Ingrians or the Ingrian Finns. The Red Book of the Peoples of the Russian Empire. Tallinn: NGO Red Book, 141-146 (http://www.eki.ee/books/redbook/ingrians.shtml).

Kuusi, Matti

1994 Questions of the Kalevala Metre. In: Siikala and Vakimo (eds.), 1994, 41-55.

Lintrop, Aado

2001 "Ema haual” lego ja lauluna. In: Jaago, Tiiu and Mari Sarv (eds.), Regilaul-keel, muusika, poeetika. Tartu: Eesti Kirjandusmuuseum,299-313.

Lotman, Jurij

1984 "Agreement" and "Self-Giving” as Archetypal Models of Culture. In: Lotman, J. M. and B. A. Uspenskij. The Semiotics of Russian Culture (ed. by A. Shukman). Michigan: University of Michigan (Michigan Slavic Contributions; 11), 125-140.

Nenola-Kallio, Aili

1982 Studies in Ingrian Laments. Helsinki: Academia Scientiarum Fennica (Folklore Fellows' Communications; 234).

Oinas, Felix J.

1969 Studies in Finnic-Slavic Folklore Relations. Helsinki: Academia Scientiarum Fennica (Folklore Fellows Communications; 205).

Ross, Jaan and Ilse Lehiste

2001 The Temporal Structure of Estonian Runic Songs. Berlin and New York: Mouton de Gruyter.

Salve, Kristi

2000 Toone tare. Tähelepanekuid setu surnuitkude žanridevahelistest ja geograafilistest seostest. In: Tagasipöördumatus. Sõnad ja hääl. Tartu: Eesti Kirjandusmuuseum, 55-72.

Siikala, Anna-Leena and Vakimo, Sinikka (eds.)

1994 Songs Beyond the Kalevala. Transformations of Oral Poetry. Helsinki: Finnish Literary Society (Studia Fennica Folkloristica; 2). 
Tedre, Ülo (ed.)

1970 Eesti rahvalaulud. Antoloogia II: 2. Tallinn: Eesti Raamat (http://www.folklore.ee/laulud/erla/ E141.HTM\#L1601; http://www.folklore.ee/laulud/erla/E141.HTM\#L1602).

Valk, Ülo

2000 Regilaul kui kommunikatsioon teispoolsusega: dialoogist nägemuseni. In: Jaago, Tiiu and Ülo Valk (eds.), Kust tulid lood minule... Artikleid regilaulu unrimise alalt 1990. aastatel. Tartu: Tartu Ülikooli kirjastus, 245-276.

Vinogradov, G. S. and Lozanova, A. I.

1941 Г. С. Виноградов, А. Н. Аозанова, Пкачи и сказы. In: Фольклор Карело-Финской ССР. Петрозаводск, 105-131.

\section{MEDŽANRSKA PREHAJANJA ŽALOSTINK IN LJUDSKIH STOPIČNIH PESMI EPSKE PESNITVE KALEVALA V BALTSKO-FINSKEM KULTURNEM PROSTORU}

Medžanrske povezave med žalostinkami in stopičnimi ljudskimi pesmimi epske pesnitve Kalevala med stevilnimi baltsko-finskimi ljudstvi in etnijami so zelo različne. V Kareliji (podobno kakor v zahodni Rusiji), se izvajanje žalostink (narekanje) kot poetski kod razlikuje od drugega pesemskega izročila. Tam sta pesemska poetika in jezik žalostink zelo bogati, celo epsko mogočni. Pesemsko besedišče in način ustvarjanja pesmi sta oblikovala poseben sklenjen sistem, le z nekaj odcepi v druge pesemske žanre. Med baltsko-finskimi ljudstvi Ingermanije (Voti, Izohoriani in lokalni Finci) kakor tudi med Seti so žaostinke mnogo bližje stopičnim pesmim epske pesnitve Kalevala. Lahko bi govorili o sorodnosti v pesniškem jeziku in tudi v načinih predstavitev. Med Estonci in Finci, ki pripadajo protestantski veri (ne pa tudi omenjena ljudstva), je petje žalostink ali narekanje skoraj popolnoma izginilo iz njihovega izročila.

Stopične nekromantične (mrliške) balade iz Kalevale so zastopane v folklori številnih baltskofinskih ljudstev (tudi Estoncev). Vsebinsko so te pesmi v nekaterih pogledih zelo blizu pogrebnim žalostinkam (narekanju). Take pesmi pojejo o pogovorih na grobovih, v obliki dialoga, bodisi ko je pokojni poklican na pomoč siroti ob njenih stiskah, ki jih doživlja v vsakdanjem življenju, bodisi ko je pokojni celo povabljen, naj vstane iz groba in iz zemlje ponudi roko živim v pomoč. Prošnje so zaman in $v$ takih pesmih je razpoloženje žalobno in čustveno, zelo podobno kakor $v$ baladah. Pesmi vsebujejo arhaične koncepte (npr. resnične priložnosti za komunikacijo z mrtvimi), a so v resnici bolj moderne zgodbe, v katerih je "nenaravna" prošnja prikazana kot nekaj nenavadnega, kar se ne more uresničiti. Funkcijsko so bile pesmi del svatbenih šeg, v primerih, ko so bili nevestini bližnji sorodniki ali celo starši, pokojni.

Zaradi tako očitnih podobnosti imamo lahko žalostinke za mogoč vir tem za "sodobne" balade. Razvoj pa je bil pri različnih baltsko-finskih ljudstvih različen. Vozadju različnih razvojnih procesov pa lahko odkrivamo razločke med severnimi in vzhodnimi (Karelijci, kot tudi Vepsijci), kot nasprotne pa med južnimi in zahodnimi (Ingrijci, Setijci, Estonci, Finci) ljudstvi, ki imajo 
različne vzroke: to so družbeni, spolni, verski razločki in povezave z okoljem in načinom življenja teh ljudstev. Tudi naselitveni vzorci so vplivali na to, da se so se razširili sodobnejši koncepti in modni tokovi. V širšem smislu pa je mogoče o stopični "Kalevalini pesemski tradiciji (in podobno tudi o žalostinkah ali narekanju) razpravljati tudi kot neke vrste okolju, $v$ katerem so opazne pomembne spremembe v izročilu.

Assoc. Prof. Dr. Madis Arukask, University of Tartu, Institute of Estonian and General Linguistics, Ülikooli 18, 50090 Tartu, Estonia,madis.arukask@ut.ee 